\title{
Biological control agents in the integrated nematode management of pepper in Egypt
}

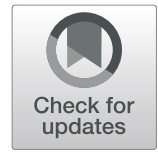

Mahfouz M. M. Abd-Elgawad(B)

\begin{abstract}
Pepper is an important vegetable crop in Egypt and worldwide. Yet, it is usually attacked and damaged by numerous plant-parasitic nematodes (PPNs) especially root-knot nematodes in Egypt. This review summarizes ecology, biology, and economic value of such nematodes from the standpoint of pest management. The use of sound cultural practices and other phytosanitary measures against PPNs of pepper should be sought. Biological control agents (BCAs) rank high among other PPN management options on pepper plants given their outstanding role in sustainable agriculture. Therefore, BCAs especially those reviewed herein due to their usefulness in reducing PPN populations and increasing pepper yield should be incorporated into pepper management systems. Further aspects of BCA biology and ecology should better be understood to let them fit into existing or emerging integrated pest management strategies for growing pepper. Examples of commercially produced biocontrol agents that have become well established in several Egyptian markets and may be used against PPNs on pepper plants are shown.
\end{abstract}

Keywords: Biological control, Bionematicides, Integrated nematode management, Pepper, Pesticide market

\section{Background}

Pepper is a member of the Solanaceae family, which also includes important vegetables such as tomatoes, potatoes, and eggplants. All varieties of sweet and most of hot peppers belong to Capsicum annuum L. Chili peppers as a group of $C$. annuum is widely used in many cuisines as a spice to add heat to the food. The substances giving chili peppers their intensity when ingested or applied topically are capsaicin and related compounds known as capsaicinoids. Nevertheless, C. annuиm contains different varieties and groups with different tasting such as glabriusculum, bola, Bell, Cayenne, Jalapeno, and New Mexico Chile. The amount of capsaicin in hot peppers varies significantly among the varieties. However, more pungency species belongs to the genus $C$. chinense Jacq which is one of the most important sources of resistance to plant-parasitic nematodes (PPNs) (Zayed

Correspondence: mahfouzian2000@yahoo.com

Plant Pathology Department, National Research Centre, El-Behooth St., Dokki, Giza 12622, Egypt

\section{Springer Open}

et al. 2017). The hottest peppers in the world are members of this species.

In Egypt, there are many hybrids and varieties of both pungent hot-tasting and sweet-tasting pepper. Hybrids and varieties within each of these two main groups may differ in size, shape, flavor, and color with usually unchanged fruit colors when fully mature. The most recommended sweet varieties in Egypt are the local hybrids: Yusr 4 (orange), Yusr 3 (yellow), Hybrid Yusr 2, (dark green), hybrid Yusr 1 (sulfur), and Khayrat (green) while the local hot varieties are Kotof 1 (dark green) and Kotof 2 (dark green). Pepper can grow in Egypt at different seasons: about 45-60 days old seedlings may be transplanted in March (early summer season), April and May (summer season), and July and August (fall or Nili season). Additionally, colored pepper varieties are cultivated under plastic and net houses in April and May (summer season) and in July, August, and September (fall/winter season). Pepper fruits begin maturity stage 2.5-3.5 months after transplanting, and harvest occurs 2-4 months thereafter, depending on the pepper variety and temperature. 
Factually, the most common peppers are green varieties but colorful ones began to spread during the last decade in Egypt. Cultivation of the colorful varieties is significantly increasing because in addition to local consumption of colored pepper, its exportation can provide a significant source of foreign currency. Colored pepper is one of the staple crops for the consumer market especially for European and some Arab Gulf countries. An increase in the demand during the winter months (January, February, and March), a period in which the harvest of crops ends in Europe such as the Netherlands and Spain, usually provides an opportunity for exporting to the European market during this period at good prices. Admittedly, success of cultivating the colored pepper is backed by suitable environmental conditions in Egypt for excellent plant growth and fruit set as well as a highquality yield. Thus, there is a continuous expansion of pepper cultivation to newly reclaimed areas of Egypt (Zayed et al. 2017). Nevertheless, such an expansion via reclaimed wide desert land entails the danger of growing pepper seedlings infected with the nematodes. The implication is that pepper growth and yield, as any other crop introduced to reclaimed soil, is threatened by the nematodes that invade the newly planted area via infected seedlings, organic fertilizers, plant materials, irrigation, and machinery (Abd-Elgawad et al. 2016 and Abd-Elgawad 2020a, b). Also, mulching virgin soil with fertile, but probably nematode-infested, silty soil from the Nile Valley to improve soil quality before planting possible infested material may aggravate the infection (Abd-Elgawad and McSorley 2009). Over time, the nematode populations develop and reproduce rapidly, and progressive increases in pepper yield losses are assumed. Abd-Elgawad (2014) estimated annual yield losses of pepper due to damage by PPNs in Egypt as $22 \%$ of total yield or $183,489.6 \mathrm{t}$ of actual annual yield loss in 2012. However, PPN populations may affect pepper yields differently based on the pathogenicity and level of the associated nematode species as well as the interacting biotic and abiotic factors influencing the cultivated pepper. Hence, improved methods for sampling are needed for exact quantification of such harmful nematodes (Abd-Elgawad 2016a, b). Many nematode species have also been shown to predispose pepper to infection by bacterial or fungal pathogens or to transmit virus diseases, which contribute to more indirect yield losses (Noling 2019).

Ibrahim (2006) compiled the following PPN genera (with related species) from pepper field soils as economically important pests: Hemicycliophora arenaria, Meloidogyne (M. incognita, $M$. javanica, M. arenaria, $M$. cruciani, M. exigua, $M$. hapla), Pratylenchus ( $P$. neglectus, $P$. penetrans), Nacobbus aberrans, and Trichodorus ( $T$. viruliferus, $T$. allius). Generally, the life cycle of PPNs mostly includes the egg, four larval stages, and the adult male and female. The first stage larvae molt to the second stage within the egg which hatches to juveniles that move to search and infect plant roots or in some cases foliar tissues. Host searching usually occurs within films of water around soil particles, root surfaces, or foliar tissues. Nematode feeding usually happens along the root surface for root-parasitic nematodes. Generally, PPNs may be classified as migratory endoparasites (e.g., lesion nematodes: Pratylenchus spp.), semiendoparasites (e.g., reniform nematodes: Rotylenchulus spp.), sedentary endoparasites (e.g., root-knot nematodes (RKNs): Meloidogyne spp.), and ectoparasitic nematodes (e.g., spiral: Helicotylenchus). For most PPN species, about 50-100 eggs are produced per female: some genera such as Meloidogyne, may produce up to 2000 eggs. Viable eggs hatch under adequate environmental conditions, and the life cycle is completed within 4 to 8 weeks; usually, relatively high temperature hastens the nematode development where optimal soil temperature ranges 21.1-26.7 ${ }^{\circ} \mathrm{C}$ (Noling 2019).

\section{PPNs of pepper in Egypt}

Out of sight, out of light, and consequently out of much consideration are often the role of soil-borne nematodes when the reason for a yield loss of a crop such as pepper is being sought. Such a general statement is true for PPNs especially in developing countries. Generally, PPNs are microscopic roundworms that feed on plant roots, and their geographical distribution is highly dependent on temperature, soil type, and cropping history. In pepper-planted areas, these nematodes survive in soil and plant tissues, and several species may occur in a field. The host range varies from one to another of the above-mentioned species (Ibrahim 2006). Symptoms of nematode infestation also vary according to the nematode species and crop type but are often non-specific (yellowing, wilting, stunting, and decrease in growth of pepper plant parameters which finally cause yield reduction). A few nematodes especially root-knot nematodes, however, cause typical symptoms on roots of infested plants.

\section{Root-knot nematodes (Meloidogyne spp.)}

These are obligate endoparasites of crop roots. One of the important factors that enhance importance of RKNs is its broad host range. The second-stage juvenile $\left(\mathrm{J}_{2}\right)$ hatches from the eggs and is worm-shaped. Backed by soil moisture, they move within the soil to enter the roots of susceptible pepper plants. Once inside the roots, they stop moving and modify the pepper root cells, while the host roots typically react to the infestation with the formation of galls (Ploeg and Aguiar 2019). While the presence of galls is indicative of a root-knot nematode 
infection, the size and shape of the galls differ in different crops. The galls on pepper roots are generally not as obvious and large as in some other vegetable crops such as tomato (Fig. 1). However, an infected pepper root system may harbor millions of RKN eggs. Inside these galls, the nematodes develop into adult females. Each female can produce several hundreds of eggs which are contained in a gelatinous matrix. These eggs are generally deposited on the outside of the roots where $\mathrm{J}_{2}$ can emerge to repeat the life cycle. This latter (from $\mathrm{J}_{2}$ to $\mathrm{J}_{2}$ ) is mostly determined by the soil temperature. Under warm conditions (about $28^{\circ} \mathrm{C}$ ), the life cycle can be completed in less than 4 weeks. Thus, during one cropping season, several life cycles can be completed. In other words, low nematode population densities at planting can rapidly increase to high populations when conditions are favorable.

In newly reclaimed land of Egypt same as in some pepper-planted areas of California, the relatively warm soil temperatures in combination with the predominant light soil types, sufficient soil moisture, and the frequent cropping of excellent RKN-host crops provide an ideal scheme for RKNs to raise to damaging population densities. In bell peppers, RKNs can cause direct yield loss via fewer and smaller fruits. Nevertheless, because of wilting and stunting caused by Meloidogyne spp. (Fig. 1) and other soil-borne pathogens, fruits are also more susceptible to sun-burn leading to considerable loss in marketable yields. Hence, RKNs are major constraints for horizontal expansion of pepper production in Egyptian sandy soils and represent the most widespread and significant PPN genus damaging many plant species in
Egypt (Ibrahim et al. 2010 and Abd-Elgawad 2020a). Root-knot nematodes were detected in $96.26 \%$ of the surveyed fields in reclaimed lands (Bakr et al. 2011). The survey represented different categories of light soils, i.e., El-Beheira (El-Tahrir), Minufiya (El-Sadat), and Sharkiya (El-Salhiya) governorates. The same trend was more recently reported in nearby areas (Abd-Elgawad 2019a). Nonetheless, RKN population levels may remarkably vary from one field to another due to different nematode control tactics and strategies as well as production practices and edaphic and biological factors.

Frequently, PPNs have over-dispersed or aggregated distribution in Egypt (Abd-Elgawad 1992; Abd-Elgawad and Hasabo 1995 and Abd-Elgawad et al. 2016) and worldwide (Duncan and Phillips 2009 and Abd-Elgawad and Askary 2015) in general. Therefore, symptoms of RKN infection tend to occur in more or less definite areas where pepper seedlings fail to develop normally. Stunted plants with decline symptoms often happen in patches of non-even growth rather than as a uniform damage of pepper over the field area (Fig. 2). Unless a proper measure for RKN control is followed, an infested field with nematode pests, which has only a few such patchy areas at the season start, may then increase in size of the infested areas until the whole area cultivated to pepper will be almost infested. Pepper plants infested by RKNs are often more deteriorated by weeds than those without nematode infection (Schroeder et al. 2004). When plants are severely infected by RKNs, the normal root system is reduced to a limited number of severely RKN-galled roots with a completely disorganized vascular system. The RKN-infected roots are

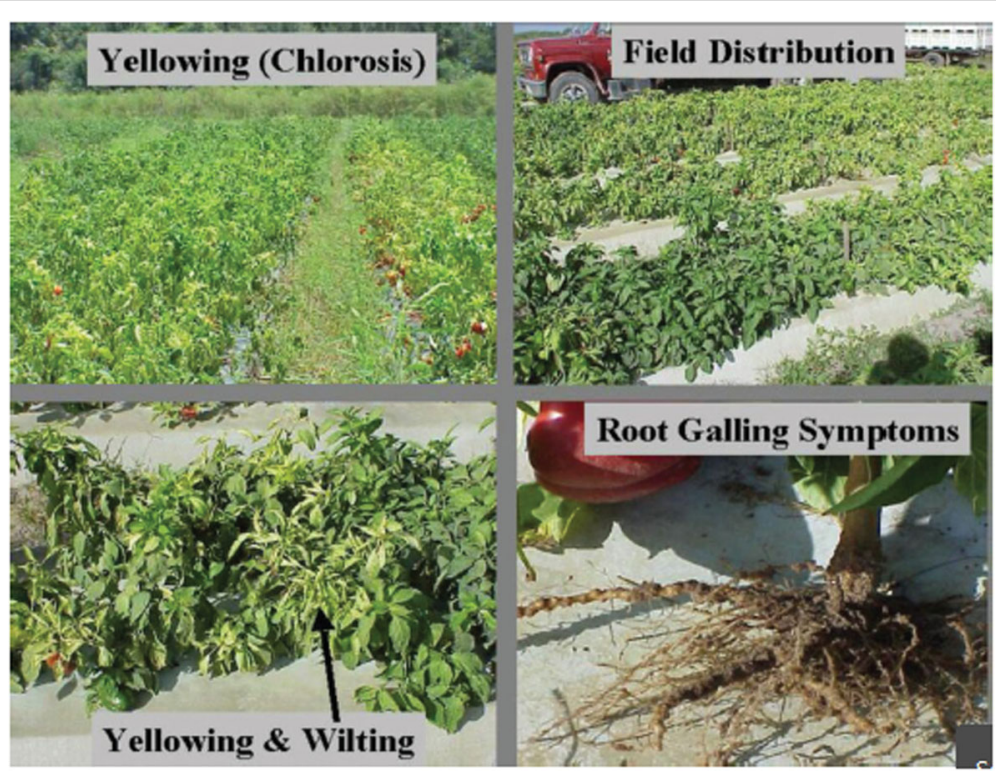

Fig. 1 Wilting, yellowing, and stunting of pepper due to the root-knot nematode (Meloidogyne spp.). Note the formation of galls on roots (Noling 2019) 


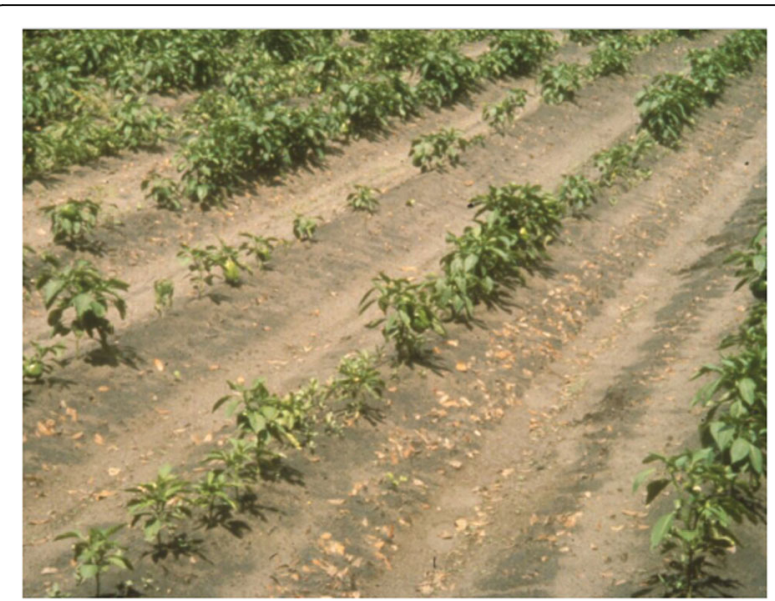

Fig. 2 A pepper field showing patchy areas in the form of stunting and seedling mortality due to root-knot nematode (Meloidogyne spp.) infestation (Noling 2019)

seriously hampered in their main functions of uptake and transport of water and nutrients. At season end, the infected plants do not flower normally and therefore produce poor quality fruits. Moreover, infected pepper plants are more vulnerable to get drought damage. Rootlets are almost completely absent at severe infestation which may render plant death. Infection by additional subterranean pests and/or pathogens may extend plant damage to further roots. Eventually, plant damage and yield loss are based on nematode population level, the degree of host suitability, production practices (e.g., Abd-Elgawad 2019a), and biological and environmental conditions.

\section{Action threshold and methods of RKN management on pepper}

Pepper yield loss is often correlated to pre-plant infestation densities in soil and/or previous crop roots. Such a loss increases as infestation level increases. Action threshold necessitates RKN control if any individual of Meloidogyne spp. was found per $100 \mathrm{~cm}^{3}$ of pepper-planted soil in Egypt and other countries (Abd-Elgawad and Askary 2015). This pre-plant threshold may not be utilized on growing plants. So, any presence of RKNs at pre-planting proposes a potentially real problem, especially on sandy soil and in warm seasons which support high RKN infection and multiplication. Strictly speaking, nematode management should primary include applying biocontrol tactics and strategies in addition to the use of a few nonchemical means such as quarantine, horticultural sanitation, use of resistant plant varieties, solarization of the soil before planting, adequate fertilization, removal of infected plants and weeds, and finally chemical nematicides. Quarantine actions that have successfully achieved protection of other plant species from nematode pests should be implemented in Egypt (e.g., Inserra et al. 2005). Abd-
Elgawad (2020a) pointed out that it is timely to motivate private and governmental sectors to fulfill the needs of our nationally certified seedlings. All stakeholders in Egypt should address the problem collectively and, especially, allocate enough capital to produce enough certified seedlings of economically important plant species and prepare pertinent experts who can carefully apply quarantine regulations. Pre-plant sampling of nematodes is basic to the quarantine programs primary in pepper nurseries. These programs should focus on selecting nursery locations to avoid runoff water from infested fields and phytosanitary measures to prevent contamination of planting material and equipment in nurseries and non-infested areas. Hence, nematode-free tools and devices must be utilized. Otherwise, such instruments must be always disinfested prior to being used in pepper nurseries and non-infested fields. Unfortunately, many growers are forced to get uncertified pepper seedlings from informal nurseries of private markets since certified seedlings are relatively expensive and not easily available in Egypt. Limitation in distribution of certified seedlings is further aggravated due to lack of awareness of pepper nematodes by many resource-poor growers (Abd-Elgawad 2019a, b). Egyptian quarantine on certifiable pathogens should also include bacteria, fungi, and other transmissible pathogens (AbdElgawad et al. 2016). Abd-Elgawad and McSorley (2009) proposed guiding nurserymen in Egypt to move the nurseries to sites that can produce nematode-free planting material and to convince growers to refrain from mulching virgin soil with infested soil from the Nile Valley. Additionally, irrigation with some forms of running water, such as aqueducts, canals, and inland waterways, has been recognized to perform a serious source of inter-field contamination by both nematodes and other soil-borne pathogens especially several fungal species which can spread widely and shortly via water movement.

Morra and Bilotto (2006) reported that in European and Mediterranean regions, soil solarization, vegetable grafting, and resistant cultivars are appropriate alternatives to the use of hazardous chemicals to control soil-borne plant pathogens. They found that "Graffito" was the most promising rootstock due to its resistance to Phytophthora capsici and its tolerance to M. incognita. "Gc 1002" appeared useful only in pepper-planted soils infested by $P$. capsici alone and/or infested by low concentrations of RKNs. Another important trait of these two rootstocks was their lack of adverse effects on the agronomic behavior of the grafted pepper varieties. Graft incompatibility, reduction of vegetative growth, lower fruit yield, and smaller fruit size were never observed. Thus, Morra and Bilotto (2006) concluded that solarization is the cheapest soil treatment and is effective under tunnels; it could be used effectively in a biennial rotation involving grafted pepper plus solarization. 
Also, one of the most effective, economical, environmentally safe methods to reduce pepper yield losses from nematode diseases is to use pathogen-resistant cultivars. Aguiar et al. (2014) found resistant bell pepper cultivars "Carolina Wonder" and "Charleston Belle" to be effective in reducing damage by $M$. incognita. Moreover, they indicated that different nematode inoculum levels also failed to affect the yield of the susceptible cultivar "Crusader" which exhibited tolerance; its yield was not affected by RKN infection. So, they concluded that resistant cultivars may provide a useful tool in a nonchemical management strategy. Such resistant cultivars may be used in crop sequence. However, weed hosts of Meloidogyne such as the solanaceous nightshade plants need to be controlled if rotation crops are to be used successfully (McKenry and Roberts 1985). Moreover, when the resistant "Carolina Wonder" and the susceptible "Baron" pepper cultivars were planted in soil with high RKN infestation level, the resistant pepper yielded about $40 \%$ more than the susceptible variety. Therefore, Ploeg and Aguiar (2019) stated that the use of nematode-resistant varieties looks promising as it leaves a low nematode infestation level with more pepper yield under high initial nematode pressure. However, the suitability of such pepper varieties under commercial growing practices remains to be tested (Ploeg 2019 and Ploeg and Aguiar 2019). Bell pepper in general appears more tolerant to root-knot nematodes than some other vegetable crops, but the relationship between pre-plant RKN levels in soil and the growth, yield, and at-harvest nematode levels should further be determined for Egyptian pepper varieties. Zayed et al. (2017) have not listed the above-mentioned tolerant/resistant cultivars in Egypt. Despite the resistance of the two above-mentioned pepper cultivars, expression of resistance is heat sensitive (Noling 2019). So, characterizing the usefulness of these varieties under the highest soil temperature in Egypt is needed. Like tomato, use of these varieties may have to be restricted to winter and spring plantings when cooler soil temperatures prevail. Therefore, it is difficult to predict risks on crop damage and decide on nematode management strategies based on the results from pre-plant samples.

In case of necessity, chemical nematicides may be used due to their ability to reduce the highest densities of nematodes in the soil in a short period to avoid significant pepper yield losses. The Egyptian Ministry of Agriculture (Anonymous 2018) recommended such nematicides as cadusafos (Rugby $10 \mathrm{G}$ ), oxamyl (Oxanem $24 \%$ SL, Vydate $10 \%$ GR and $24 \%$ SL), fenamiphos (Dento 40\% EC, Fenatode 10\% GR), ethoprophos (Nemacap 20\% EC), and fosthiazate (Nemathorin 10\% GR) to manage RKNs on solanaceous crops. Egypt resembles New Mexico and Arizona, USA, where the lack of economically feasible sustainable RKN management options force the most growers who produce stably priced high value specialty crops such as chili pepper to fumigate with 1,3-dichloropropene (Thomas 1994 and Thomas and Nischwitz 2018). Although a limited number of RKN-resistant pepper cultivars are available for a few pepper genotypes produced in other countries, none are available for Egypt: like other states such as New Mexico. Thus, such chemicals can achieve PPN control and increase pepper yields. However, due to possible health hazards and environmental pollution by chemical nematicides, biocontrol tactics and strategies should be developed as a key element in integrated pest management (IPM) programs of pepper pathogens and pests. Therefore, relevant reports of biological control agents for controlling nematodes of pepper in Egypt are presented herein so as to focus on data that give evidence for the usefulness of such new trends. Hence, the relevant expertise of research institutions in Egypt and elsewhere is compiled in this review as a pre-requisite to develop the necessary tactics for safe and effective biocontrol while offering a realistic management strategy of PPNs on pepper.

\section{Lesion (Pratylenchus spp.), reniform (Rotylenchulus spp.) and other nematodes}

Apparently, the damage and widespread occurrence brought about by RKNs frequently covers any significance of other PPN genera such as Pratylenchus and Rotylenchulus on pepper. Admittedly, lesion nematodes have a wide host range feeding on almost every species of cultivated plants. Numerous weeds also are quite suitable hosts. Many species of Pratylenchus are known to parasitize on crops, grasses, and weeds in Egyptian soils (Abd-Elgawad 2019a). Thus, it is probable to plant pepper in the above-mentioned soils that are infested with one or more of the above-mentioned Pratylenchus species (Ibrahim 2006). On the other hand, some authors reported pepper cultivars to be non-hosts of $R$. reniformis (MacGowan 1977). Yet, Acosta et al. (1987) compared the two chemical nematicides oxamyl and phenamiphos for their control of $R$. reniformis on two species of pepper (Capsicum annum and C. frutescens). Both nematicides reduced $R$. reniformis populations levels equally well, while pepper plants treated with oxamyl (at 0.56 and $1.12 \mathrm{~kg}$ a.i./ ha) provided greater numbers of fruit and heavier fruit. Oxamyl at a dosage of $1.12 \mathrm{~kg}$ a.i./ha gave greater numbers of fruit for both species than at $0.56 \mathrm{~kg}$ a.i./ha, but heavier fruit for C. annum only.

Other species related to the nematode genera Ditylenchus, Meloidogyne, Tylenchorhynchus, and Tylenchus were associated with pepper plants grown in newly reclaimed area in North West Egypt (Korayem et al. 2015). Also, Taha (2018) showed the association of the 
nematode genera Meloidogyne, Helicotylenchus, Pratylenchus, Rotylenchulus, Tylenchorhynchus, Paratylenchus, and Tylenchus with vegetables including pepper in Shoubra El-Kheima, El-Qalioubia governorate, Egypt. The frequency of occurrence, relative abundance, and population density of these PPN genera found in soil samples collected from the rhizosphere of pepper plants were $96.5 \%$, $45 \%$, and 186.3 nematodes per $250 \mathrm{~cm}^{3}$ soil, respectively. Abd-Elgawad and Askary (2015) reported also action thresholds for PPN on pepper plants to be $1,80,40$, and 10 nematodes per $100 \mathrm{~cm}^{3}$ for sting (Belonolaimus spp.) lesion (Pratylenchus spp.), stunt (Tylenchorhynchus spp.), and awl (Dolichodorus spp.) nematodes, respectively (Abd-Elgawad and Askary 2015). Nonetheless, additional host plants, other PPN species, and biological and edaphic factors may alter the threshold or economic injury level across these nematode's geographic distribution worldwide (Wang 2019). Nevertheless, except RKNs, information is scanty about the damage caused by such other nematodes to pepper in Egypt. Management measures similar to that applied for the RKNs may also be adopted to control such nematode genera.

\section{Bringing together the expertise for biocontrol of PPNs on pepper}

A few research and review articles that can provide insights into the advancement in the area of nematode management on pepper especially via biocontrol tactics are compiled hereafter.

Chaudhary and Kaul (2013) evaluated the comparative efficacy of Pasteuria penetrans under the influence of organic amendments of four oil seed cakes, namely, $A z a-$ dirachta indica (Neem), castor (Ricinus communis), mustard (Brassica campestris), and Citrullus (Citrullus colocynthis) on suppression of populations of Meloidogyne incognita on Chili pepper plants. Oil seed cakes were applied at the rate of $500 \mathrm{~kg} / \mathrm{ha}$, either individually or in combination with one dose of P. penetrans (100 g/ $\mathrm{kg}$ soil). Among the four oil cakes tested, the combined application of $P$. penetrans with castor oil cake seemed to be more promising in the management of $M$. incognita in chili as it resulted in greater RKN suppression and improved plant health. Meyer et al. (2011) evaluated seed meal mixes of Brassica juncea (Bj) and Sinapis alba (Sa) against $M$. incognita infecting pepper plants. Rates of soil application $(\% \mathrm{w} / \mathrm{w})$ for the phytotoxicity study were $0.5 \mathrm{Sa}, 0.2 \mathrm{Bj}, 0.25 \mathrm{Sa}+0.25 \mathrm{Bj}, 0.375 \mathrm{Sa}+0.125$ $\mathrm{Bj}, 0.125 \mathrm{Sa}+0.375 \mathrm{Bj}$, and 0 , applied $0-5$ weeks before transplant. Overall, $0.2 \% \mathrm{Bj}$ was the least toxic meal to pepper seedlings. So, $\mathrm{Bj}$ and some $\mathrm{Bj}+\mathrm{Sa}$ mixtures can be applied close to transplant to suppress $M$. incognita populations on pepper. Also, a seed meal mixture could be selected to provide activity against more than one pest or pathogen. For pepper, care should be taken in formulating mixtures so that Sa rates are low compared to $\mathrm{Bj}$. Yet, biofumigation is a sustainable method of soil management in pepper rotations that can increase soil organic matter, moderate soil $\mathrm{pH}$, suppress weeds and soil-borne pathogens through glucosinolates, and increase water infiltration (Guerrero-Díaz et al. 2013; Laznik et al. 2014 and Rudolph et al. 2015). Specifically, biofumigation using both mustard (Brassica juncea) and broccoli (Brassica oleracea) caused considerable reduction in RKN populations in a 2-year (2011-13) pepper field study (Rudolph et al. 2015). Admittedly, many microorganisms have indispensible roles in the biofumigation. For example, brassica seed meal amendments facilitate the amplification of certain bacterial groups which are known to degrade recalcitrant chemistries including industrial wastes (Mazzola et al. 2015). Moreover, application of mustard seed meal alters bacterial community in soil and induces plant systemic resistance due to production of nitric oxide by bacteria (Meyer et al. 2011 and Dutta et al. 2019). On the other hand, application of moringa (Moringa oleifera) leaf powder at 40,60 , and $80 \mathrm{~g} / \mathrm{L}$ increased sweet pepper yield and decreased RKN populations confirming their potential in nematode management (Sowley et al. 2014). Sweet pepper plants treated with $80 \mathrm{~g} / \mathrm{L}$ of moringa leaf powder per plot recorded the highest mean value of plant height, number of leaves, number of fruits per plant, fruit weight per plant, total yield per plot, and the thickest plant girth. Likewise, Tagetes erecta cultivated with chili pepper, or rotated and their residues incorporated into soil, can reduce significantly root galling induced by RKNs (Thomas and Nischwitz 2018).

The combined action of organic amendment and solarization (often referred as Biodisinfestation) has shown its effectiveness to control M. incognita in pepper. Mechanism of action includes reduction of available oxygen due to anaerobiosis (by microbes) coupled with effect of temperature and release of ammonia and nitrous oxide by decomposing organic matter (GómezRodríguez et al. 2017 and Dutta et al. 2019). However, high temperature did not produce a sustained reduction in $M$. incognita populations possibly because the temperature effect did not translocate to lower depths of soil leading to recolonization and reinfestation by remaining RKN populations during longer duration crop cycle (Gómez-Rodríguez et al. 2017). This does not negate that the beneficial effects of short-term solarization have been documented (Wang and McSorley 2008 and Abd-Elgawad et al. 2019). Also, Kihika et al. (2017) found that $M$. incognita $\mathrm{J}_{2} \mathrm{~s}$ were more attracted by plant volatile signatures to three pepper cultivars than to the pepper accession, relative to controls. The $\mathrm{J}_{2} \mathrm{~S}$ showed their ability to follow the gradient of chemical concentration, i.e., chemotaxis, which provides insights into 
RKN-host pepper interactions, creating new opportunities for plant breeding programs to manage RKNs. Other trials have proved the beneficial effects of various BCAs on RKNs with consequent increase of pepper plant yields and/or growth parameters. These included applying the bacterium $P$. penetrans on $M$. incognita (Dube and Smart 1987), the two fungi Burkholderia cepacia and Trichoderma virens, singly and together, against $M$. incognita (Meyer et al. 2001), both Pochonia chlamydosporia and Pseudomonas fluorescens (Rao et al. 2004), and P. chlamydosporia (Tzortzakakis 2007) on M. incognita.

\section{Developing biocontrol tactics and strategies of PPNs on Pepper in Egypt}

Given the above-mentioned multiple views of success in controlling PPNs on pepper using ecofriendly control methods, the core of this review is to draw attention to their applications including the various factors and mechanisms affecting the PPN problem, optimize their biocontrol tactics, and focus on new useful trends of integrated nematode management (INM) in Egypt. For such an INM, two types of sampling should be a preconsideration. Adequate PPN sampling method, time, and process are necessary to detect and diagnose nematode problems, if any, via proper collection of relevant soil and plant tissues (Abd-Elgawad 2019a, b). These samples must be sent to a nematode lab, such as Diagnostic Services at the Special Unit of the National Research Centre, Dokki, Giza governorate for analyses prior to pepper transplanting. The level of nematode numbers and their species/genera identified in these samples at pre-planting of nurseries and fields determine if nematode control is required. Another type of rational sampling to maximize isolation of BCAs should be used (Abd-Elgawad 2020c). The overall goal of such functional sampling is to isolate (in large numbers), identify, and deploy highly effective strain(s) against nematode pests before their development into registered, readyfor-sale plant protection products.

Foreign BCA products are available but local ones may be more adapted and less expensive without significant risk to Egyptian fauna and flora. The relatively high efficacy demonstrated generally by indigenous BCAs (AbdElgawad and Kabeil 2012; Table 1) that supports the need for their development against PPNs on pepper. Improving their efficacy should further be tried in earnest. For example, increasing the efficacy of Trichoderma harzianum was possible when it was integrated with organic amendments such as oil cakes or wheat bran-peat preparations (Abd-Elgawad and Kabeil 2012). Applying such tactics and the likes is very important because BCAs are generally slower acting, less effective, and more inconsistent than control normally achieved with chemicals. Therefore, Abd-Elgawad (2020d) reviewed the different groups of BCAs to identify conditions and practices that affected their use for nematode management and alternatives to maximize their useful applications against PPNs. Such various approaches, which were reported (Abd-Elgawad 2020d) to minimize costs, facilitate availability, optimize application, and enhance efficacy of these BCAs, should be considered to manage PPNs of pepper. For example, the bionematicide producer can act at the same time as the distributor. Furthermore, the producer may nominate some of its employees with experience in nematicidal application. Factually, those experts can better recognize bionematicide-related issues such as the viability of BCAs, contamination, and BCA fate/persistence. Admittedly, being responsible for producing, distributing, applying, and following up BCAs all by the same company will reduce costs and increase profit margins while guarantee sound application and follow-up of the PPN management programs.

Such biocontrol tactics and strategies are especially important, since there are many bionematicides which are or are likely to become widely available soon.

Table 1 Key commercially available bionematicides and chemical nematicides, their applications rates, and prices in Egypt

\begin{tabular}{|c|c|c|c|}
\hline Active ingredient & Product name & $\begin{array}{l}\text { Application rate } \\
\left(\text { product/Feddan }^{-1}\right)^{+}\end{array}$ & $\begin{array}{l}\text { Price pe } \\
\text { Feddan }\end{array}$ \\
\hline $\begin{array}{l}\text { Abamectin produced during the fermentation process of Streptomyces } \\
\text { avermitilis (soluble concentrate at } 20 \mathrm{~g} / \mathrm{l} \text { ) }\end{array}$ & Tervigo 2\% SC & $2.5 \mathrm{l} /$ feddan & L.E. 2000 \\
\hline $\begin{array}{l}10^{9} \mathrm{CFU} / \mathrm{ml} \text { of Serratia sp., Pseudomonas sp., Azotobacter sp., Bacillus } \\
\text { circulans, and B. thuringiensis }\end{array}$ & Micronema & $30 \mathrm{l} /$ feddan (thrice)/year & L.E. 600 \\
\hline $10^{8}$ units/ml Purpureocillium lilacinus & Bionematon & $2 \mathrm{l} /$ feddan/year & L.E. 500 \\
\hline $10^{9}$ bacterium cells of Serratia marcescens $/ \mathrm{ml}$ water & Nemaless & $10 \mathrm{l} /$ feddan (thrice)/year & L.E. 600 \\
\hline Cadusafos (O-ethyl S,S-bis (1-methylpropyl) phosphorodithioate) & Rugby $10 \mathrm{G}$ & $24 \mathrm{Kg} / \mathrm{feddan}$ & L.E. 6480 \\
\hline Oxamyl (methyl 2-(dimethylamino)-N-(methylcarbamoyloxy)-2oxoethanimidothioate) & Vydate $24 \%$ SL & $4 \mathrm{l} / \mathrm{feddan}$ (twice)/year & L.E. 280 \\
\hline
\end{tabular}

There are broad host range claims by the manufacturer's product labels which have not necessarily been confirmed in independent trials

+Figures given for comparative purposes when products are uniformly applied to the soil (except oxamyl for foliar application too). For some products and other, including low-value, crops, product may be incorporated into field soil, potting mix, or applied in greenhouses for which different rates apply (Wilson and Jackson 2013; Hammam et al. 2016; Abd-Elgawad 2020a) 
Therefore, identification of research priorities for harnessing fungal and bacterial nematicides in sustainable agriculture as well as understanding their ecology, biology, mode of action, and interaction with other agricultural inputs was recently addressed by Abd-Elgawad and Askary (2018). They reviewed fungal and bacterial nematicides with their mechanisms of action and other relevant information such as the active ingredient, product name and type of formulation, producer, targeted nematode species and crops, and country of origin. Such information in addition to factors affecting success of biocontrol programs against PPNs (Abd-Elgawad 2016c and Abd-Elgawad and Askary 2020) can present highlights for their use against nematodes of pepper.

The formal bionematicide that is recommended by the Egyptian Ministry of Agriculture (Anonymous 2018) is abamectin (Tervigo $2 \% \mathrm{SC}$ ). It is produced by a living organism, during the fermentation process of the actinomycete Streptomyces avermitilis (Wilson and Jackson 2013). The active ingredient is abamectin $(20 \mathrm{~g} / \mathrm{l})$. Its unique chelated formulation secures effective protection of the active ingredient for direct contact with PPNs and best soil penetration. The iron chelate can supply a micronutrient iron (Fe) which enhances soil fertility and health by increasing cation exchange capacity, raises chlorophyll content, and promotes root mass. The abamectin consists of about $80 \%$ and $20 \%$ of avermectin $B_{1 a}$ and $B_{1 b}$, respectively (Fisher and Mrozik 1989). Its mechanism of action is materialized in blocking the transmission of electrical activity in invertebrate nerve and muscle cells mostly by enhancing the effects of glutamate at the invertebrate-specific glutamategated chloride channel with minor effects on gammaaminobutyric acid receptors (Bloomquist 2003). So, it causes an influx of chloride ions into the cells, leading to hyperpolarization and subsequent paralysis of nematode neuromuscular systems. The product has a strong activity against numerous genera of PPNs (Anonymous 2020). Its soluble concentrate (SC) formulation is a solid active ingredient dispersed in water. Such a formulation is favorable due to merits such as effectiveness, ease of use and absence of dust when compared to formulation types such as wettable powder, and emulsifiable concentrate formulations. Within the soil, abamectin acts mainly by contact activity. Fortunately, a few new BCA products tested for PPN control have also been able to compete with chemical nematicides in price. Some of them are even less expensive (Table 1) which may expand their use to larger areas. Labels of these bionematicides may offer devices and guidelines to help stakeholders and growers to store, prepare, and apply these recently marketed biocontrol agents. For instance, optimum temperature to store, required rate, dose, or active ingredient to apply for a defined area, and best time of application are usually mentioned. They may also provide other new rate modifying recommendations.
Researchers should further grasp the complex network of interactions among biotic and abiotic factors in intimate contact with these BCAs on pepper plants to maximize their gains. To promote biocontrol of pepper nematodes, application of the BCA products will need to fit into existing or emerging IPM strategies. So, opportunities that facilitate their incorporation into pepper management systems should be seized, such as developing new (compatible) application methods or leveraging synergies/additive effects between BCAs and other pest management tactics (Abd-Elgawad and Askary 2018, 2020). In this vein, chemical nematicides can be replaced to some extent by bionematicides to reduce the impact on the environment. As the use of broad-spectrum chemical nematicides decreases due to regulatory concerns and progress on BCA production and application advances, it is anticipated that the significance of BCAs as an integral component of sustainable PPN management systems on pepper plants will develop into a more distinguished role (e.g., Lamovšek et al. 2013).

\section{Conclusions}

Pepper is an important vegetable crop in Egypt but its crop yield may be severely damaged by PPNs. Although chemical nematicides can effectively control the nematodes, their excessive use may pollute the environment and cause health hazards. Therefore, prevention of PPN introduction especially into newly reclaimed areas by establishment of relevant regulations and certified seedlings should be promoted. Sound agricultural practices should be utilized but biological control agents rank high among other PPN management options given their prominent role in sustainable agriculture. Consequently, the different groups of BCAs especially those who proved to be useful in reducing PPN populations and increasing pepper growth parameters and/or yield should be incorporated into pepper management systems. Obviously, different aspects of BCA biology and ecology should better be grasped in order to let them fit into existing or emerging integrated pest management strategies for cultivating pepper.

\section{Abbreviations \\ BCAs: Biological control agents; RKNs: Root-knot nematodes; INM: Integrated nematode management; IPM: Integrated pest management; PPN: Plant- parasitic nematode; $J_{2}$ : Second-stage juvenile}

\section{Acknowledgements}

This study was supported in part by the NRC In-house project No. 12050105 entitled "Pesticide alternatives against soil-borne pathogens and pests attacking economically important solanaceous crops." Facilities offered by The National Research Centre are appreciated.

\section{Author's contributions}

The author has developed and implemented this review article and written it. The author(s) read and approved the final manuscript. 


\section{Funding}

Financial support made by the National Research Centre, Egypt, is gratefully acknowledged.

\section{Availability of data and materials}

The datasets used and/or analyzed during the current study are available from the corresponding author on reasonable request.

\section{Ethics approval and consent to participate}

Not applicable

\section{Consent for publication}

Not applicable

\section{Competing interests}

The author declares that he has no competing interests.

Received: 11 April 2020 Accepted: 25 May 2020

Published online: 05 June 2020

\section{References}

Abd-Elgawad MM (1992) Spatial distribution of the phytonematode community in Egyptian citrus groves. Revue Nematol 14:367-373

Abd-Elgawad MMM (2014) Yield losses by phytonematodes: challenges and opportunities with special reference to Egypt. Egyptian J Agronematol 13(1): 75-94

Abd-Elgawad MMM (2016a) Biological control agents of plant-parasitic nematodes: a review. Egypt J Biol Pest Cont 26(2):423-429

Abd-Elgawad MMM (2016b) Use of Taylor's power law parameters in nematode sampling. Int J PharmTech Res 9(12):999-1004

Abd-Elgawad MMM (2016c) Comments on the use of biocontrol agents against plant-parasitic nematodes. Int J PharmTech Res 9(12):352-359

Abd-Elgawad MMM (2019a) Plant-parasitic nematodes of Strawberry in Egypt: a review. Bull. NRC $43: 7$ https://doi.org/10.1186/s42269-019-0049-2

Abd-Elgawad MMM (2019b) Towards optimization of entomopathogenic nematodes for more service in the biological control of insect pests. Egypt J Biol Pest Cont 29:77. https://doi.org/10.1186/s41938-019-0181-1

Abd-Elgawad MMM (2020a) Optimizing biological control agents for controlling nematodes of tomato in Egypt. Egypt J Biol Pest Cont 30:58. https://doi.org/ 10.1186/s41938-020-00252-x

Abd-Elgawad MMM (2020b) Managing nematodes in Egyptian citrus orchards. Bulletin of the National Research Centre 44:41 https://doi.org/10.1186/ s42269-020-00298-9

Abd-Elgawad MMM (2020c) Can rational sampling maximize isolation and fix distribution measure of entomopathogenic nematodes?. Nematology 22, doi: https://doi.org/10.1163/15685411-00003350

Abd-Elgawad MMM (2020d) Plant-parasitic nematodes and their biocontrol agents: current status and future vistas. In: Ansari RA, Rizvi R, Mahmood I (eds) Management of phytonematodes: recent advances and future challenges. Springer, Germany In Press

Abd-Elgawad MMM, Askary TH (2015) Impact of phytonematodes on agriculture economy. In: Askary TH, Martinelli PRP (eds) Biocontrol agents of phytonematodes. CAB International, Wallingford, pp 3-49

Abd-Elgawad MMM, Askary TH (2018) Fungal and bacterial nematicides in integrated nematode management strategies. Egypt J Biol Pest Cont 28:74 https://doi.org/10.1186/s41938-018-0080-x

Abd-Elgawad MMM, Askary TH (2020) Factors affecting success of biological agents used in controlling plant-parasitic nematodes. Egypt J Biol Pest Cont 30:17 https://doi.org/10.1186/s41938-020-00215-2

Abd-Elgawad MMM, Elshahawy IE, Abd-El-Kareem F (2019) Efficacy of soil solarization on black root rot disease and speculation on its leverage on nematodes and weeds of strawberry in Egypt. Bull. NRC 43:175 https://doi. org/10.1186/s42269-019-0236-1

Abd-Elgawad MMM, Hasabo SA (1995) Spatial distribution of the phytonematode community in Egyptian berseem clover fields. Fundam Appl Nematol 18: 329-334

Abd-Elgawad MMM, Kabeil SSA (2012) Biological control of Meloidogyne incognita by Trichoderma harzianum and Serratia marcescens and their related enzymatic changes in tomato roots. Afr J Biotech 11:16247-16252

Abd-Elgawad MMM, Koura FFH, Montasser SA, Hammam MMA (2016) Distribution and losses of Tylenchulus semipenetrans in citrus orchards on reclaimed land in Egypt. Nematology 18:1141-1150 http://journals. indexcopernicus.com/Egyptian+Journal+of+Agronematology,p8230,3.html

Abd-Elgawad MMM, McSorley R (2009) Movement of citrus nematode-infested material onto virgin land: detection, current status and solutions with costbenefit analysis for Egypt. Egypt J Agronematol 7(1):35-48

Acosta NN, Abreu VE, Medina-Gaud S (1987) Chemical control of Meloidogyne incognita, Rotylenchulus reniformis, and Anthonomus eugenii in Capsicum annuum and C. frutescens. Nematropica 17:163-169

Aguiar JL, Bachie O, Ploeg A (2014) Response of resistant and susceptible bell pepper (Capsicum annuum) to a Southern California Meloidogyne incognita population from a commercial bell pepper field. J Nematol 46:346-351

Anonymous (2018) Adopted recommendations to combat agricultural pests (in Arabic). Commercial Al-Ahram Press, Qalioub, Egypt, Agricultural Pesticide Committee, Ministry of Agriculture, Media Support Center Press

Anonymous (2020) Tervigo 020SC: Nematicides. https://www.syngenta.co.ke/ product/crop protection/nematicides/tervigo-020sc. Accessed 4 April 2020

Bakr RA, Mahdy ME, Mousa EM (2011) A survey of root-knot and citrus nematodes in some new reclaimed lands in Egypt. Pak J Nematol 29(2):165170

Bloomquist JR (2003) Chloride channels as tools for developing selective insecticides. Arch Insect Biochem Physiol 54(4):145-156. https://doi.org/10. 1002/arch.10112

Chaudhary KK, Kaul RK (2013) Efficacy of Pasteuria penetrans and various oil seed cakes in management of Meloidogyne incognita in chilli pepper (Capsicum annuum L.). J Agric Sci Tech 15:617-626

Dube B, Smart GC Jr (1987) Biological control of Meloidogyne incognita by Paecilomyces and Pasteuria penetrans. J Nematol 19:222-227

Duncan LW, Phillips MS (2009) Sampling root-knot nematodes. In: Perry RN, Moens M, Starr JL (eds) Root-knot nematodes. CAB International, St. Albans, pp 275-300

Dutta TK, Khan MR, Phani V (2019) Plant-parasitic nematode management via biofumigation using brassica and non-brassica plants: current status and future prospects. Curr PI Biol 17:17-32

Fisher MH, Mrozik H (1989) Chemistry. In: Campbell WC (ed) Ivermectin and Abamectin. Springer-Verlag, New York, pp 1-23

Gómez-Rodríguez O, Corona-Torres T, Aguilar-Rincón VH (2017) Differential response of pepper (Capsicum annuum L.) lines to Phytophthora capsici and root-knot nematodes. Crop Protect 92:148-152

Guerrero-Díaz MM, Lacasa-Martínez CM, Hernández-Piñera A, Martínez-Alarcón V, Lacasa-Plasencia A (2013) Evaluation of repeated biodisinfestation using Brassica carinata pellets to control Meloidogyne incognita in protected pepper crops. Spanish J Agric Res 11:485-493

Hammam MMA, El-Nagdi WMA, Abd-Elgawad MMM (2016) Biological and chemical control of the citrus nematode, Tylenchulus semipenetrans (Cobb, 1913) in Egypt. Egypt J Biol Pest Cont 26(2):345-349

Ibrahim IKA (2006) Diseases and pests of vegetable crops and control methods. Monshaat Al-Maarf Publisher, Alexandria, Egypt

Ibrahim IKA, Mokbel AA, Handoo ZA (2010) Current status of phytoparasitic nematodes and their host plants in Egypt. Nematropica 40:239-262

Inserra RN, Stanlet JD, O'Bannon JH, Esser RP (2005) Nematode quarantine and certification programmes implemented in Florida. Nematol Medit 33:113-123

Kihika R, Murungi LK, Coyne D, Ng'ang'a M, Hassanali A, Teal PEA (2017) Torto B (2017) Parasitic nematode Meloidogyne incognita interactions with different Capsicum annum cultivars reveal the chemical constituents modulating root herbivory. Sci Rep 7:2903. https://doi.org/10.1038/s41598-017-02379-8

Korayem AM, Youssef MMA, Mohamed MMM, Lashein AMS (2015) Plant-parasitic nematodes associated with different plants grown in newly reclaimed area in North West Egypt. Egyp. J Agronematol 14:127-136

Lamovšek J, Urek G, Trdan S (2013) Biological control of root-knot nematodes (Meloidogyne spp.): microbes against the pests. Acta Agric Slovenica 101(2): 263-275

Laznik Ž, Trdan S, Vučajnk F, Bohinc T, Vidrih M (2014) Cruciferous plants' use as biofumigants in potato against wireworms. Acta Agric Scand Sec B, Soil PI Sci 64(7):606-614

MacGowan JB (1977) The Reniform Nematode. Nematology Circular No. 32. Florida Department of Agriculture and Consumer Services, USDA, Florida, USA

Mazzola M, Hewavitharana SS, Strauss SL (2015) Brassica seed meal soil amendments transform the rhizosphere microbiome and improve apple production through resistance to pathogen reinfestation. Phytopathology 105:460-469 
McKenry MV, Roberts PA (1985) Phytonematology study guide. Oakland: Cooperative Extension University of California, Division of Agriculture and Natural Resources, Publication 4045, $56 \mathrm{p}$.

Meyer SF, Roberts DP, Chitwood DJ, Carta LK, Lumsden RD, Mao W (2001) Application of Burkholderia cepacia and Trichoderma virens, alone and in combinations, against Meloidogyne incognita on bell pepper. Nematropica 31:75-86

Meyer SLF, Zasada IA, Orisajo SB, Morra MJ (2011) Mustard seed meal mixtures: management of Meloidogyne incognita on pepper and potential phytotoxicity. J Nematol 43:7-15

Morra L, Bilotto M (2006) Evaluation of new rootstocks for resistance to soilborne pathogens and productive behaviour of pepper (Capsicum annuum L. ). J Hort Sci Biotech 81(3):518-524

Noling JW (2019) Nematode management in tomatoes, peppers, and eggplant. University of Florida publication Series no. ENY-032, USA, p 16

Ploeg A (2019) University of California IPM Pest Management Guidelines: peppers. Agriculture and Natural Resources, UC, ANR Publication 3460

Ploeg A, Aguiar JL (2019) Root-knot nematodes on bell peppers. University of California Cooperative Extension, Farm Advisors, pp 1-3

Rao MS, Dhananjay N, Shylaja M (2004) Biointensive management of root-knot nematode on bell pepper using Pochonia chlamydosporia and Pseudomonas fluorescens. Nematol Medit 32:159-163

Rudolph RE, Sams C, Steiner R, Thomas SH, Walker S, Uchanski ME (2015) Biofumigation performance of four brassica crops in a green chile pepper (Capsicum annuum) rotation system in southern New Mexico. HortScience 50:247-253

Schroeder J, Thomas SH, Murray LW (2004) Root knot nematodes affect annual and perennial weed interactions with chile pepper. Weed Sci 52:28-46

Sowley ENK, Kankam F, Adomako J (2014) Management of root-knot nematode (Meloidogyne spp.) on sweet pepper (Capsicum annuum L.) with moringa (Moringa oleifera Lam.) leaf powder. Arch Phytopath PI Prot 47:1531-1538

Taha EH (2018) Abundance and distribution of plant parasitic nematodes associated with some different plant hosts. Egypt Acad J Biol Sci 10(2):99109

Thomas SH (1994) Influence of 1,3-dichloropropene, fenamiphos, and carbofuran on Meloidogyne incognita populations and yield of chile peppers. Suppl J Nematol 26:683-689

Thomas SH, Nischwitz C (2018) Plant-parasitic nematodes of New Mexico and Arizona. In: Subbotin S, Chitamber J (eds) Plant-parasitic nematodes in sustainable agriculture of North America, sustainability in plant and crop protection. Springer Nature, Switzerland, pp 113-130

Tzortzakakis EA (2007) The effect of the fungus Pochonia chlamydosporia on the root-knot nematode Meloidogyne incognita in pots. Russian J Nematol 15:8994

Wang K (2019) Reniform nematode (Rotylenchulus reniformis) Linford and Oliveira (Nematoda: Tylenchida: Tylenchoidea: Hoplolaimidea: Rotylenchulinae). University of Florida publication Series no. EENY-210 (IN367), p 4.

Wang KH, McSorley R (2008) Exposure time to lethal temperatures for Meloidogyne incognita suppression and its implication for soil solarization. J Nematol 40:7-12

Wilson MJ, Jackson TA (2013) Progress in the commercialisation of bionematicides. BioControl 58:715-722

Zayed GA, Abdo AA, Hammam HB, Khafagi EY (2017) Cultivation and production of pepper and eggplant in Egypt. Technical issue No. 15, General Administration of Agricultural Culture, Ministry of Agriculture, Egypt.

\section{Publisher's Note}

Springer Nature remains neutral with regard to jurisdictional claims in published maps and institutional affiliations.

\section{Submit your manuscript to a SpringerOpen ${ }^{\circ}$ journal and benefit from:}

- Convenient online submission

- Rigorous peer review

- Open access: articles freely available online

- High visibility within the field

- Retaining the copyright to your article

Submit your next manuscript at $\boldsymbol{\nabla}$ springeropen.com 